\title{
Modeling Potential Geographical Distribution of the Wild Nests of Melipona capixaba Moure \& Camargo, 1994 (Hymenoptera, Apidae): Conserving Isolated Populations in Mountain Habitats
}

\author{
Bruna Danielle Vieira Serra ${ }^{1}$, Paulo De Marco Júnior ${ }^{2 *}$, \\ Caroline Côrrea Nóbrega ${ }^{3} \&$ Lucio Antonio de Oliveira Campos ${ }^{4}$
}

\author{
${ }^{1}$ Programa de Pós-graduação em Entomologia, Universidade Federal de Viçosa - UFV, Viçosa, MG, Brasil \\ ${ }^{2}$ Laboratório de Ecologia Teórica e Síntese, Departamento de Ecologia, Instituto de Ciências Biológicas - ICB, \\ Universidade Federal de Goiás - UFG, Goiânia, GO, Brasil \\ ${ }^{3}$ Programa de Pos-graduação em Ecologia \& Evolução, Universidade Federal de Goiás - UFG, Goiânia, GO, Brasil \\ ${ }^{4}$ Departamento de Biologia Geral, Universidade Federal de Viçosa - UFV, Viçosa, MG, Brasil
}

\begin{abstract}
Mountain endemic species are usually related to a restricted set of ecological conditions, presenting a fragmented range interspersed by lowland that may prevent its dispersion and favors isolation and speciation. Here we investigate the pattern of distribution of Melipona capixaba, an endemic bee species of mountain areas of central Atlantic forest by means of species distribution modeling procedures. We aimed to describe the potential distribution of this species considering broad climatic variables and evaluate the possible non-equilibrium of its range using models that simulate restricted dispersion by inclusion of spatial variables. The models indicate that the known occurrence points are located in a small fraction of its potential distribution, which is fragmented in different mountain ridges. Models without spatial variables predicted a larger range and an overlap with the distribution of a closely related species, M. scutellaris. Ensemble models also indicate areas to future search for new population of this species, as well as important areas for its conservation.
\end{abstract}

Key words: Endangered Species, Melipona capixaba, Mountain Endemism, Restricted Distribution, Species Distribution Modeling

\section{Introduction}

The evolutionary specialization of a species to a particular climate regime and the inability of the species to adapt to new environmental conditions are important factors that limit its dispersion (Wiens 2004). On the other hand, conservation of the ecological niches on an evolutionary time scale (Peterson et al. 1999) may play a key role in promoting vicariant speciation in landscapes where favorable habitats alternate with unfavorable habitats, such as mountainous regions (Wiens 2004; Kozak et al. 2006). In mountainous systems species with some level of climatic specialization do not disperse between different suitable patches due to their inability to transpose lowlands (Wiens 2004; Kozak et al. 2006).

Endemic species are susceptible to greater risk of extinction (Hero et al. 2005). These species share two aspects that

\footnotetext{
*Send correspondence to: Paulo De Marco Júnior

Laboratório de Ecologia Teórica e Síntese,

Departamento de Ecologia, Instituto de Ciências

Biológicas - ICB, Universidade Federal de Goiás - UFG

CP 131, CEP 74001-9700, Goiânia, GO, Brasil

E-mail: pdemarco@icb.ufg.br
}

negatively affect their conservation. In one hand they tend to be naturally rare and by definition present restricted geographic distributions. On the other hand, due to their rarity, little is known about their biology and distribution. In this context, species distribution models are a tool now widely used to help establishing conservation strategies for these species (Pearson et al. 2007; Siqueira et al. 2009; Almeida et al. 2010). For similar reasons, these techniques have also been used to investigate process of speciation and endemism in mountainous regions (Kozak \& Wiens 2006). But it is important to highlight that, at the same time, modeling rare species represent special limits imposed by the shortage of distributional information (Almeida et al. 2010; Pearson et al. 2007). Here we adhere to the view that, despite the few occurrence records of rare species provide incomplete descriptor of its niche, they may generate useful predictions of suitable areas for the species (Le Lay et al. 2010). These maps, hereafter potential distribution areas, creates new opportunities to find unknown populations or setting priority areas for conservation (Rodriguez et al. 2007; Nóbrega \& De Marco 2011). 
Species distribution models assume that the species occurrences are determined by the immediate response to environmental variations (species distribution equilibrium in relation to climate) (Araújo \& Pearson 2005). However, under historical non-equilibrium the species distribution models can produce misleading estimates, which was recently evaluated by species in its initial stages of colonization (De Marco et al. 2008). In this case, the distribution is currently determined by the environment (Rahbek et al. 2007), but some differences between the current and potential distribution are expected due to the failure of the dispersion process in reaching all possible suitable areas (De Marco et al. 2008). Another non-equilibrium scenario would be observed in populations with restricted distribution that do not disperse due to geographic barriers or biological interactions. In this case, the models will predict extensive areas, larger than those where the species actually occurs, and depict the potential distribution to which there were no limiting factors to the occupation of its niche.

Here we investigate the possible historic non-equilibrium in the distribution of the mountain-restricted species using as model organism the social bee Melipona capixaba Moure \& Camargo, 1994 (Hymenoptera: Apidae). This bee is endemic to the highlands of the southwest region of Espírito Santo, Brazil. Its known distribution is restricted to areas between 900 and $1000 \mathrm{~m}$ in elevation of the Atlantic Forest biome (Moure \& Camargo 1994; Melo 1996). In this scenario, it is relevant to evaluate differences on modeled potential distribution with and without constrains on species dispersal. This investigation may help to understand the importance of geographical and environmental barriers, besides the relation of its distribution with other related species. Additionally, this species is considered "vulnerable" on the Brazilian List of the Threatened Species due to the degradation of its natural habitat associated with its restricted and fragmented distribution (IPEMA 2007). We aim to provide potential distribution maps to help determining priority areas for new inventories and help to find new populations of this species.

\section{Material and Methods}

\section{Study species}

M. capixaba lives in eusocial colonies constructed in hollow trees. Workers measure approximately $10.8 \mathrm{~mm}$ in length and have a predominantly dark-brown color (Moure \& Camargo 1994). Most known nests of M. capixaba are in beehives that were cut and moved from the original tree branches by local residents or built of crude boxes for beekeeping.

\section{Field study}

Wild nests of $M$. capixaba are rare and difficult to locate, as their entrance is well camouflaged. To find the nests in their natural environment, we were helped by local residents and collected GPS information on the exact location of the nest in the field. We only use wild nests information in the modeling procedures. This conservative choice excluded the information from Melo (1996), which came from beehives transferred to new areas near owner's residences.

The municipalities where the nests were observed are located in the southwestern mountainous region of Espírito Santo, Brazil (Brejetuba, Domingos Martins, Vargem Alta and Venda Nova do Imigrante). The vegetation of this region is the Atlantic forest classified by Veloso et al. (1991) as Tropical Rain Forest. This area is part of the cold, rugged and rainy region, average minimum temperature on coldest month between 7.3 and $9.4^{\circ} \mathrm{C}$ and average maximum temperature of the warmest month between 25.3 and $27.8^{\circ} \mathrm{C}$. The rainy season occurs between October and April and average annual rainfall varies from 943 to $1906 \mathrm{~mm}$. The average relative humidity is $86.3 \%$ (Nimer 1972).

\section{Environmental variables}

The environmental variables used to modeling procedures were mean annual temperature, temperature seasonality (coefficient of variation), average temperature of the driest quarter, annual precipitation, precipitation seasonality (coefficient of variation) and precipitation of warmest quarter obtained from the WORDCLIM database (http:// www.worldclim.org). Selection of bioclimatic variables was based on our assessment of their relevance for the species. Temperature and precipitation have direct effects on the thermoregulatory capacity and external activity in the nests of social bees (Moritz \& Crewe 1988; Hilário et al. 2007), abilities that affect reproduction and species persistence in the environment. Additionally, two topographic variables were used, elevation and slope, derived from the Hydro- $1 \mathrm{~K}$ global digital elevation model (http://eros.usgs.gov). All variables were rescaled to a resolution of 2.5' (approximately $4.5 \mathrm{~km}$ ) by taken the mean values of the overlapped 30" (app. $1 \mathrm{~km}$ ) original grid. As biotic interactions are not included in the model, a larger cell is usually advised to assure that local biotic interactions will not inflate false positive values (Soberón 2007).

Some of the procedures (e.g. Mahalanobis distance) depends on the existence of more points than variables to the estimation of components in a variance-covariance matrix. Considering this and the problems associated with multi-collinearity between environmental variables, the present study utilizes an innovative approach based on dimensionality reduction of environmental data through a principal component analysis (PCA). We evaluate the PCA for the environmental variables in all cells and the first five axes of the PCA account for $95.7 \%$ of the total variation (Table 1). These five axes were used in all models with the advantage of being not correlated and allow generating predictions even in a small occurrence dataset ( 6 points). 
Table 1. Environmental variables and their corresponding axes of the PCA used in the species distribution modeling procedures.

\begin{tabular}{lrrrrr}
\hline \multicolumn{1}{c}{ Environmental variables } & F1 & F2 & F3 & F4 & F5 \\
\hline Altitude & 0.347 & -0.419 & -0.293 & 0.278 & -0.445 \\
Annual precipitation & -0.412 & -0.034 & -0.399 & -0.008 & -0.141 \\
Precipitation seasonality (coefficient of variation) & 0.129 & -0.624 & 0.382 & 0.397 & 0.395 \\
Precipitation of warmest quarter & -0.274 & 0.071 & -0.566 & 0.521 & 0.450 \\
Annual mean temperature & -0.461 & -0.120 & 0.242 & -0.044 & 0.214 \\
Temperature seasonality (coefficient of variation) & 0.363 & 0.496 & 0.120 & 0.077 & 0.424 \\
Mean temperature of driest quarter & -0.461 & -0.188 & 0.210 & -0.231 & -0.006 \\
Slope & 0.248 & -0.365 & -0.413 & -0.658 & 0.446 \\
Explained portion & 48.300 & 17.800 & 17.200 & 7.451 & 4.938 \\
Accumulated portion & 48.300 & 66.100 & 83.300 & 90.751 & 95.689 \\
\hline
\end{tabular}

\section{Spatial variables}

The distribution of a species is a spatial process mediated by the dispersal to suitable sites (Soberón 2007). Considering current knowledge, it is expected that areas near to known occurrence records are more reachable, increasing the chance to find new populations of a rare species. Thus, the inclusion of spatial variables (latitude and longitude for points of occurrence) allows for evaluating how the potential distribution models behave under restrictions on the ability of the species dispersion and simulates a non-equilibrium scenario (De Marco et al. 2008). All analyses of potential distribution were made with and without the addition of spatial variables.

\section{Species distribution modeling}

We developed models for the potential distribution of M. capixaba using three modeling procedures with different levels of complexity: Maxent (Maximum Entropy) version 3.3.3 (Phillips et al. 2006), Mahalanobis distances (Farber \& Kadmon 2003) and BIOCLIM (Beaumont et al. 2005). The three methods were used to assess uncertainty in model results (Elith et al. 2006).

The estimates of suitability were transformed into binary predictions (presence/absence) by means of the threshold derived from the ROC curve (Receiver Operating Characteristic) so that only values above the threshold were considered suitable locations for the species (Elith et al. 2006). Evaluation of the models utilized the "area under the ROC curve" (AUC).

\section{Results}

Fourteen wild nests of M. capixaba were found, with 10 unique points (i.e., those located in different cells of the environmental variable grid, Figure 1). All AUCs are higher than 0.98 and thus provide reliable estimates of distributions, in a statistical sense.

The model obtained with the BIOCLIM without spatial variables (Figure 2a) predicted the occurrence of M. capixaba in the Chapada Diamantina in Bahia (400 to $2033 \mathrm{~m}$ in elevation), in Minas Gerais in the Serra do Espinhaço (800 to $2062 \mathrm{~m}$ ) of the central region of the state, the Serra da Canasta (900 to $1496 \mathrm{~m}$ ) in the southwest region and Serra da Mantiqueira (1200 to $2798 \mathrm{~m}$ ) in the south and southeast regions of Minas Gerais, Brazil. It was also predicted in the Serra dos Órgãos in the state of Rio de Janeiro (100-2275 m), Serra do Mar (500-1877 m) in the central region of São Paulo and Serra da Mantiqueira in the northeast region of this state, as well as the Serra do Caparaó (997 to 2892 m) along the southwestern border of Espírito Santo with Minas Gerais, near the Pedra Azul, Forno Grande and Serra do Castelo State Parks. In the model adding latitude and longitude (Figure $2 \mathrm{~b}$ ), the prediction of $M$. capixaba occurrence is restricted to southwestern Espírito Santo.

The Mahalanobis distance predicts the occurrence of the species only in southeastern Espírito Santo both including or excluding spatial predictors (Figure $2 \mathrm{c}, \mathrm{d}$ ), but adding space restrict a bit the estimated distribution.

In the Maxent model without space (Figure 2e) M. capixaba is predicted to occur in the mountains and plateaus of eastern and southeastern Brazil near the coast encompassing several Brazilian States, in areas from the mountain ranges Mantiqueira, Mar, Diamantina, Espinhaço, Canastra, Caparaó and their extensions. When adding space variables (Figure 2f) the occurrence of the species is constrained to central and southwestern Espírito Santo, near the coast and the interior region, in southeastern Minas Gerais near the border with Espirito Santo and in the central region of Rio de Janeiro, in the Serra dos Órgãos.

The models described above may be combined to produce a map which identifies the number of models predicting the presence of the species at each point (Figure 3). In the model without space there was an overlap of the three procedures (BIOCLIM, Mahalanobis distance and Maxent) in parts of the Chapada Diamantina in Bahia, Serra do Espinhaço (central region) and Serra da Mantiqueira (southeast) of Minas Gerais, southwestern highlands of Espírito Santo, Serra dos Órgãos in Rio de Janeiro and in the Serra do Mar (center) and Serra da Mantiqueira (northeast) of São Paulo (Figure $3 \mathrm{a}$ ). In the modeling procedure with space 


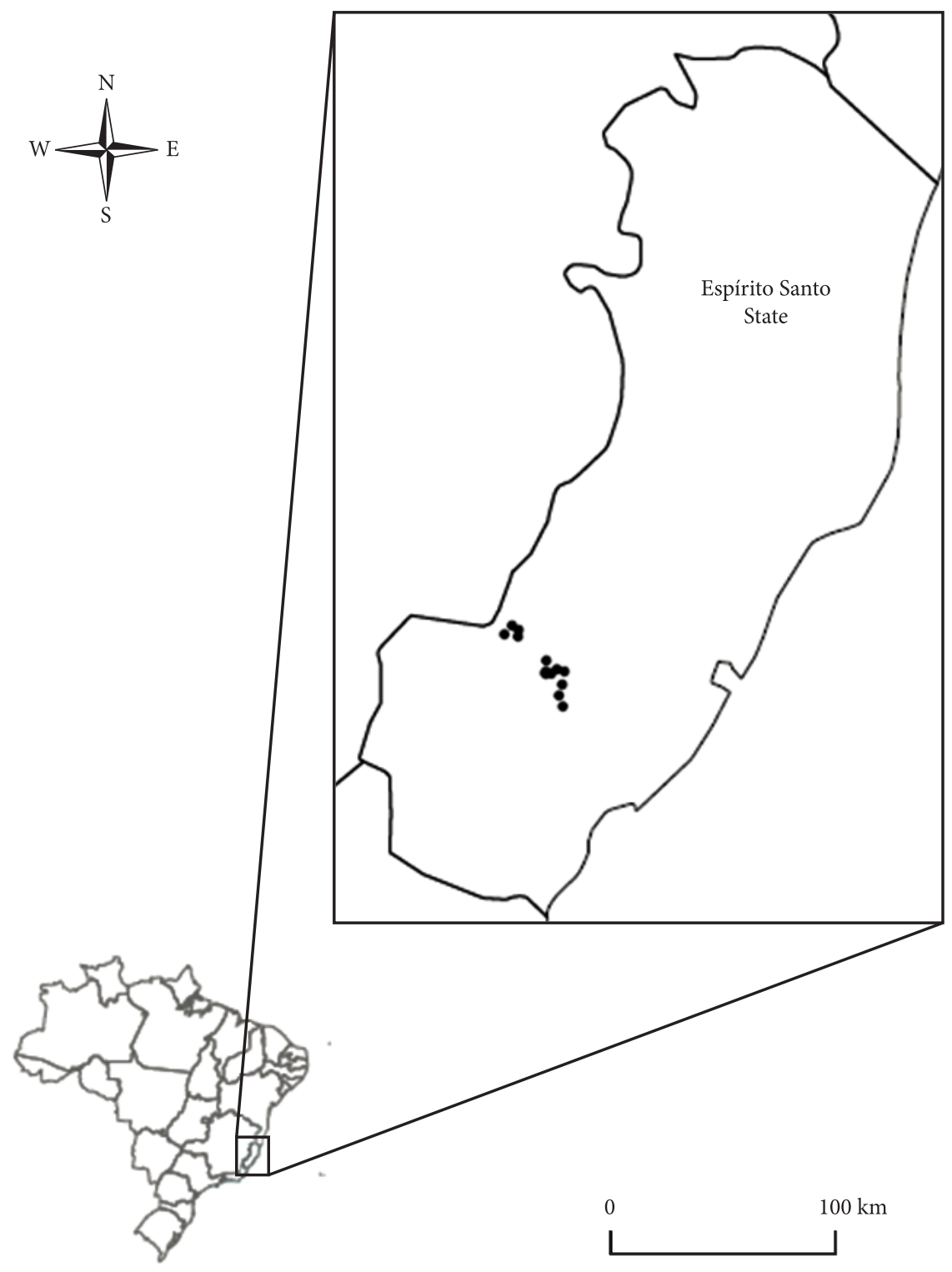

Figure 1. Map of area under study indicating the 14 wild nests of M. capixaba (some points overlap).

there was overlap in the BIOCLIM, Mahalanobis distance and Maxent only in the southeastern mountainous region of Espírito Santo (Figure 3b).

\section{Discussion}

Predicting the potential distribution of M. capixaba in models without adding spatial variables, assuming no constrain on its dispersal, resulted in its occurrence in mountainous areas near the coast, including states of northeast, south and southeast Brazil. This situation appears to represent an over-estimation of its occupation. The inclusion of spatial variables (which may represent dispersal limitation) produced models that predict its distribution only in the mountainous region of Espírito Santo, Minas Gerais and Rio de Janeiro, which seems to be more compatible with the actual knowledge of this species. The observed differences between models with and without adding spatial variables may indicate limitations in dispersion processes and, thus, highlight that this species are not in equilibrium with its potential range (De Marco et al. 2008).

BIOCLIM and Maxent models without restriction predicted occurrence of $M$. capixaba in areas of occurrence of M. scutellaris in Bahia, possibly because there is a high similarity in the climate niches of the two species. Some researchers suggest a close phylogenetic relationship between M. capixaba and M. scutellaris. According to Moure \& Camargo (1994), M. capixaba belongs to the group that includes species in northeastern Brazil and would be closely related to $M$. scutellaris, a species which geographically occurs in the Northeast of Brazil (Moure et al. 2007). Nascimento et al. (2000) reported the absence of anatomical 

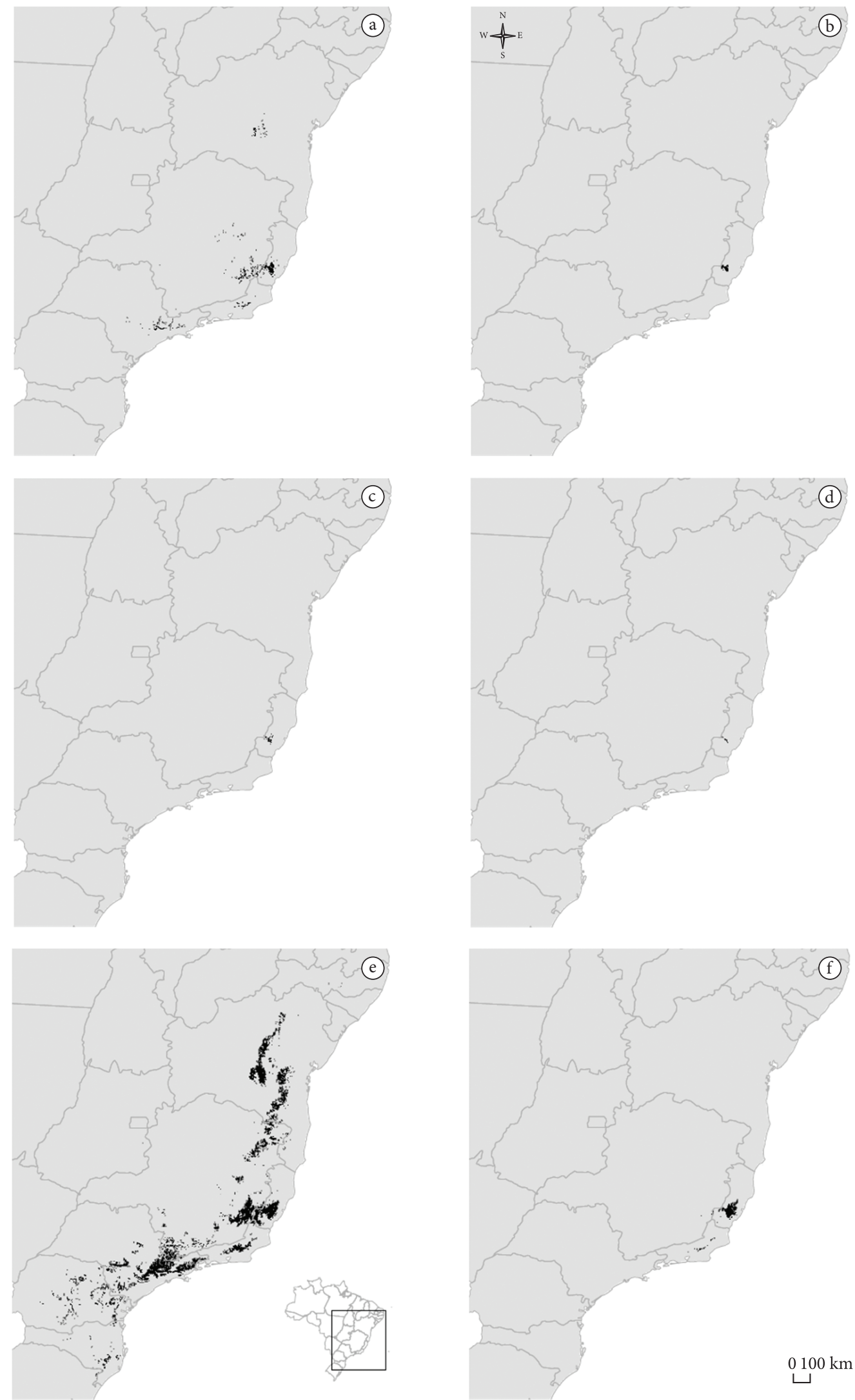

Figure 2. Prediction of potential geographical distribution of Melipona capixaba with (right) and without (left) spatial variables. Modeling using BIOCLIM ( $a$ and b), Mahalanobis distance ( $c$ and d) and Maxent models (e and f). 

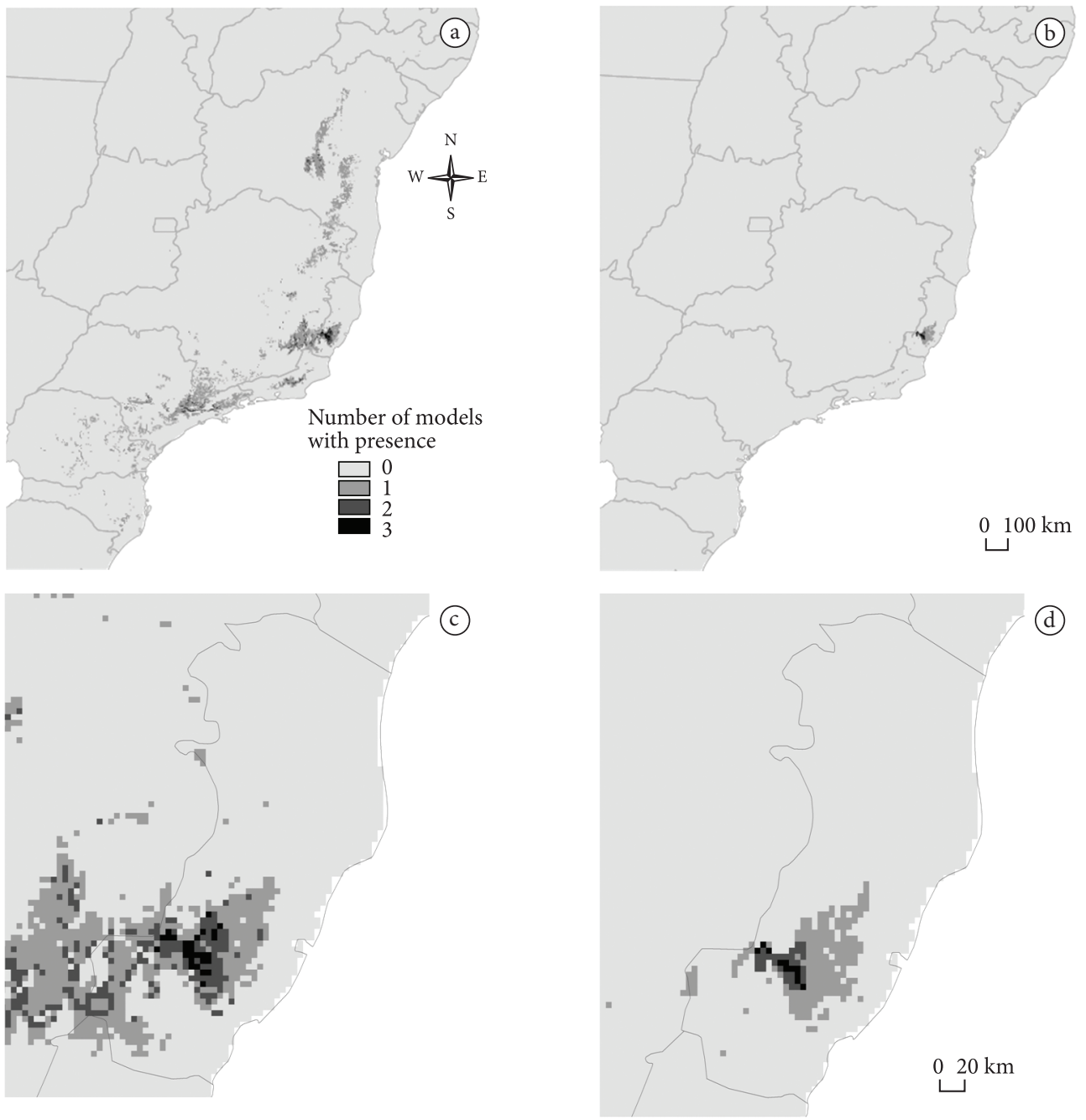

Figure 3. Map with the combination of three different procedures for modeling the potential distribution of Melipona capixaba. The color scale indicates the number of models (BIOCLIM, Mahalanobis distance and Maxent) that predict the presence of M. capixaba at any point: without ( $\mathrm{a}$ and $\mathrm{c}$ ) and with spatial variables (b and d).

and behavioral isolation mechanisms between the two species that allowed their breeding when artificially placed in the same area, suggesting that they are genetically related species and able to form hybrids. Rocha \& Pompolo (1998) verified that $M$. scutellaris originated from the Chapada Diamantina, Bahia, and M. capixaba from Venda Nova do Imigrante, Espírito Santo, also supporting that species are evolutionarily close. In this case, it is possible that the reproductive isolation between $M$. capixaba and M. scutellaris may have resulted from the disjunction of habitats, since the potential for breeding among species was maintained. Of course, a more detailed investigation of the niche evolution in Melipona, in a explicit phylogenetic context, is needed to better support the above claims.

Many studies reported predicted distribution of a species within the area of occurrence of its sister (Peterson et al. 1999). These researchers found that there was similarity in the climatic niche of allopatric pairs of bird, butterfly and mammal species on both sides of the Isthmus of Tehuantepec in Mexico. Kozak \& Wiens (2006) observed a similar situation in sister taxa of salamanders in the Appalachian Mountains in North America. Despite its geographic isolation, the climatic niches occupied by the sister taxa were generally more similar than the absent locations between these niches. The pattern observed by the authors suggests that niche conservatism played an important role in promoting allopatric speciation and endemism of the mountain in this group of vertebrates. A similar situation may be observed for M. capixaba and M. scutellaris. The mountainous regions of Espírito Santo and Bahia predicted in models without spatial variables are areas of similar climate separated by dissimilar climate between mountain ranges. Specializing in climatic niches of the two species limits is dispersion by impeding that they cross lowlands and are exposed to different climatic regimes from those to which they are 
adapted. Thus, specialization in climatic niches may play a key role in promoting vicariant isolation and speciation in landscapes where favorable habitats alternate with unfavorable habitats, as in the case of mountain regions (Wiens 2004; Kozak et al. 2006).

Areas predicted for the occurrence of M. capixaba in the model without spatial variables are those where the species could potentially survive, taking into account the variables used for construction of the models. Several factors may limit its dispersion and prevent that it reaches areas with similar climatic characteristics to those of its known occurrence points (Soberón 2007), so that distribution is restricted to localities in accordance to the models with adding spatial variables. Among these possible factors we include human influence, biotic interactions (inter-specific competition, predation), presence of geographic barriers that prevent the dispersal, the absence of some essential food source, availability of hollow trees for nest, intolerance to desiccation and heat on the lowlands. Finally, an interesting historical hypothesis is that this is a recent species which were not capable, yet, to reach all suitable areas available (historical non-equilibrium in the sense of De Marco et al. 2008). Although difficult to test with present data, this could not be sorted out and may represent a parsimonious explanation considering the plethora of events listed above.

Areas where all the generated models predict the presence of the species is probably more suitable for survival than areas where few models predict its presence. Areas where the three modeling procedures overlapped correspond to the municipalities of the mountainous southwest and central regions of Espírito Santo usually known as "Região Serrana". These areas are affected by the expansion of the forestry industry (eucalyptus and rubber), pastures, agriculture, mineral extraction of ornamental rocks and exploitation of granite (IDAF 2004). They are also subject to indiscriminate use of pesticides and slash and burn vegetation clearing for subsequent occupation with agricultural crops (Espírito Santo 2008). These practices are harmful to $M$. capixaba since they destroy possible substrates for its nesting (hollow trees) and reduce the supply and quality of available food (pollen and nectar). Additionally, the mountainous regions are important tourist destinations due to their natural attributes, which potentiate irregular occupation of the soil (IDAF 2004; Espírito Santo 2008).

We devise two practical conservation uses of the predicted distribution maps for $M$. capixaba generated here. First, it may help to identify priority areas for conservation. A set of protected units occurs within the area predicted for M. capixaba occurrence (Mata das Flores State Park, Forno Grande State Park, Pedra Azul State Park, Caparaó National Park and Cachoeira do Rio Pardo Forest Reserve). The remnants of mountain rainforest are essential for conservation of this species that suffers a high degree of threat because of its restrict distribution and intensity of human activities in its area of occurrence. Therefore, M. capixaba distribution would have larger portions contained in protected areas. The creation of new protected areas and the establishment of private reserves (Private Reserve of Nature Patrimony, PRNP) by landowners are important actions to this species that suffers a high degree of threat in terms of both the restrict distribution and intensity of human activities in its area of occurrence.

Finally, for this rare species we consider that continue effort in find new populations are of unquestionable value. Our maps suggest that planned field inspections within the mountain ridges of Espirito Santo, mainly in its north portion are still important as well as further investigations in the direction of Minas Gerais, were some models indicate suitable areas.

Modeling rare species is both a methodological challenge and a conservation imperative. Restricted distribution species are high threatened as well as they had small number of records to model its distribution. We reinforce that known limitations of incomplete description of niche space in such cases (Siqueira et al. 2009) are potentialized by complex dispersal restriction (Soberón 2007) in mountain-dwelling species. To deal with these problems, methodological advances such as the inclusion of spatial variables are important tools. However, further well designed field work based on these models are also the key both to provide better information to conservation actions as to disentangle the historical and evolutionary causes of its distribution.

\section{Acknowledgements}

We would like to thank the residents of the study area, Mr. Jacó Fileti, Mr. Jésus Falqueto, Mr. João Grecco, Mr. José Bellon, Mr. Laurentino Ambrosin, Mr. Ozenio Zorzal and Mr. Valmir Bellon for their help in locating the nests; to INCAPER for the logistical support; to CNPq for the doctorate scholarship provided to the first author and to the Graduate Program in Entomology of the Universidade Federal de Viçosa. PDM and LAOC research is supported by continuous $\mathrm{CNPq}$ productivity grants.

\section{References}

Almeida MC, Côrtes LG \& De Marco PJ, 2010. New records and a niche model for the distribution of two neotropical damselflies: Schistolobos boliviensis and Tuberculobasis inversa (Odonata: Coenagrionidae). Insect Conservation and Diversity, 3:252-256. http://dx.doi. org/10.1111/j.1752-4598.2010.00096.x

Araújo MB \& Pearson RG, 2005. Equilibrium of species' distributions with climate. Ecography, 28:693-695. http:// dx.doi.org/10.1111/j.2005.0906-7590.04253.x

Beaumont LJ, Hughes L \& Poulsen M, 2005. Predicting species distributions: use of climatic parameters in BIOCLIM and its impact on predictions of species' current and future distributions. Ecological Modelling, 186:250-269. http:// dx.doi.org/10.1016/j.ecolmodel.2005.01.030

De Marco P, Diniz-Filho JAF \& Bini LM, 2008. Spatial analysis improves species distribution modeling during range expansion. Biology Letters, 4:577-580. PMid:18664417 PMCid:2610070. http://dx.doi.org/10.1098/rsbl.2008.0210 
Elith J et al., 2006. Novel methods improve prediction of species' distributions from occurrence data. Ecography, 29:129-151. http://dx.doi.org/10.1111/j.2006.0906-7590.04596.x

Espírito Santo (Estado). Secretaria de Estado da Agricultura, Abastecimento, Aquicultura e Pesca, 2008. Plano Estratégico de Desenvolvimento da Agricultura Capixaba: novo PEDEAG 2007-2025. Available from: <http://www.seag. es.gov.br/pedeag/livro.htm>. Access in: 10 June 2011.

Farber O \& Kadmon R, 2003. Assessment of alternative approaches for bioclimatic modeling with special emphasis on the Mahalanobis distance. Ecological Modelling, 160:115-130. http://dx.doi.org/10.1016/S0304-3800(02)00327-7

Hero JM, Williams SE \& Magnusson WE, 2005. Ecological traits of declining amphibians in upland areas of eastern. Australia. Journal of Zoology, 267:221-232.

Hilário SD, Ribeiro MF \& Imperatriz-Fonseca VL, 2007. Impacto da precipitação pluviométrica sobre a atividade de vôo de Plebeia remota (Holmberg, 1903) (Apidae, Meliponini). Biota Neotropica, 7:135-143. http://dx.doi.org/10.1590/ S1676-06032007000300016

Instituto de Defesa Agropecuária e Florestal do Espírito Santo - IDAF, 2004. Plano de manejo do Parque Estadual da Pedra Azul. Serviços de Consultoria em Meio Ambiente. Relatório 199/04. Available from: <http://www.idaf.es.gov. br/Pages/wfParquePedraAzul.aspx $>$. Access in: 10 June 2011

Instituto de Pesquisa da Mata Atlântica - IPEMA, 2007. Espécies da Fauna Ameaçadas de Extinção no Estado do Espírito Santo. Vitória: Ipema.

Kozak KH, Weisrock DW \& Larson A, 2006. Rapid lineage accumulation in a non-adaptive radiation: phylogenetic analysis of diversification rates in eastern North American woodland salamanders (Plethodontidae:Plethodon). Proceedings of the Royal Society B: Biological Sciences, 273:539-546. PMid:16537124 PMCid:1560065. http://dx.doi.org/10.1098/rspb.2005.3326

Kozak KH \& Wiens JJ, 2006. Does niche conservatism promote speciation? A case study in north American salamanders. Evolution, 60:2604-2621. PMid:17263120.

Le Lay G et al., 2010. Prospective sampling based on model ensembles improves the detection of rare species. Ecography, 33:1015-1027. http://dx.doi. org/10.1111/j.1600-0587.2010.06338.x

Melo GAR, 1996. Notes on the nesting biology of Melipona capixaba (Hymenoptera, Apidae). Journal of the Kansas Entomological Society, 69:207-210.

Moritz RFA \& Crewe RM, 1988. Air ventilation in nests of two African stingless bees Trigona denoiti and Trigona gribodoi. Experientia, 44:1024-1027. http://dx.doi.org/10.1007/ BF01939912

Moure JS \& Camargo JMF, 1994. Melipona (Michmelia) capixaba, uma nova espécie de Meliponinae (Hymenoptera, Apidae) do sudeste do Brasil. Revista Brasileira de Zoologia, 11:289-296. http://dx.doi.org/10.1590/S0101-81751994000200013
Moure JS, Urban D \& Melo GAR, 2007. Catalogue of bees (Hymenoptera, Apoidea) in the neotropical region. Sociedade Brasileira de Entomologia. Available from: <http://www. moure.cria.org.br/catalogue>. Access in: 18 Aug. 2011

Nimer E, 1972. Climatologia da região sudeste do Brasil. Revista Brasileira de Geografia, 34:3-38.

Nascimento VA, Matusita SH \& Kerr WE, 2000. Evidence of hybridization between two species of Melipona bees. Genetics and Molecular Biology, 23(1):79-81. http://dx.doi. org/10.1590/S1415-47572000000100014

Nóbrega CC \& De Marco P, 2011. Unprotecting the rare species: a niche-based gap analysis for odonates in a core Cerrado area. Diversity and Distributions, 17:491-505. http://dx.doi. org/10.1111/j.1472-4642.2011.00749.x

Pearson RG et al., 2007. Predicting species distributions from small numbers of occurrence records: a test case using cryptic geckos in Madagascar. Journal of Biogeography, 34:102-117. http://dx.doi.org/10.1111/j.1365-2699.2006.01594.x

Peterson AT, Soberón J \& Sánchez-Cordero V, 1999. Conservatism of ecological niches in evolutionary time. Science, 285:1265-1267. PMid:10455053. http://dx.doi. org/10.1126/science.285.5431.1265

Phillips SJ, Anderson RP \& Schapire RE, 2006. Maximum entropy modeling of species geographic distributions. Ecological Modelling, 190:231-259. http://dx.doi.org/10.1016/j. ecolmodel.2005.03.026

Rahbek C et al., 2007. Predicting Continental-scale patterns of bird species richness with spatially explicit models. Proceedings of the Royal Society B: Biological Sciences, 274:165-174. PMid:17148246 PMCid:1685854. http://dx.doi.org/10.1098/rspb.2006.3700

Rocha MP \& Pompolo SG, 1998. Karyotypes and heterochromatin variation (C-bands) in Melipona species (Hymenoptera, Apidae, Meliponinae). Genetics and Molecular Biology, 21(1): 41-45. http://dx.doi.org/10.1590/S1415-47571998000100008

Rodriguez JP et al., 2007. The application of predictive modelling of species distribution to biodiversity conservation. Diversity and Distributions, 13:243-251. http://dx.doi. org/10.1111/j.1472-4642.2007.00356.x

Siqueira MF et al., 2009. Something from nothing: using landscape similarity and ecological niche modeling to find rare plant species. Journal for Nature Conservation, 17:25-32. http://dx.doi.org/10.1016/j.jnc.2008.11.001

Soberón J, 2007. Grinnellian and Eltonian niches and geographic distributions of species. Ecology Letters, 10:1115-1123. PMid:17850335. http://dx.doi. org/10.1111/j.1461-0248.2007.01107.x

Veloso HP, Rangel-Filho ALR \& Lima JCA, 1991. Classificação da vegetação brasileira, adaptada a um sistema universal. Rio de Janeiro: Fundação Instituto Brasileiro de Geografia e Estatística. PMCid:270254.

Wiens JJ, 2004. Speciation and ecology revisited: phylogenetic niche conservatism and the origin of species. Evolution, 58:193-197. PMid:15058732. 